\title{
Students' Motivation toward English Language Learning at Undergraduate Level
}

\author{
Mumtaz Ahmed (Corresponding author) \\ Department of English Govt. Postgraduate College of Science Samanabad Faisalabad Pakistan \\ E-mail: webmumtaz@gmail.com \\ Maria Aftab \\ Department of English University of Sargodha Women Campus Faisalabad Pakistan \\ E-mail: mariaaftab00@gmail.com \\ Humaira Yaqoob \\ Department of English University of Sargodha Women Campus Faisalabad Pakistan \\ E-mail: humaira.yaqoob4@gmail.com
}

\author{
Doi:10.7575/aiac.alls.v.6n.3p.230 \\ URL: http://dx.doi.org/10.7575/aiac.alls.v.6n.3p.230
}

Received: 20/02/2014

Accepted: 30/04/2015

\begin{abstract}
The main purpose of this descriptive research is to explore the fact that why students are less motivated towards English language learning at undergraduate level. It also throws light upon the very facts of motivation with regard to the factors like student-teacher relationship, class room environment, self esteem or self respect, and willingness to communicate. Motivation plays a major part in learning a second language. It creates very powerful communicative factors by planting in them the seeds of self confidence. It is the responsibility of a teacher to create a comfortable environment in the class. The teacher should make the environment student-centered because if a student feels valued in the class, he or she would be more interested in learning a second language. The population of this research consisted of 199 students at undergraduate level from University of Sargodha (UOS) Women Campus Faisalabad, Pakistan. For this purpose the researchers formed a questionnaire on the four point Likert's scale on the different levels of motivation and gave the students maximum time to solve the questionnaire. The results and findings of the research show that motivation has a great role in learning with regard to the above mentioned factors.
\end{abstract}

Keywords: Motivation, ELT, ESL, Pakistan, learner, undergraduate

\section{Introduction}

Communication plays a vital role in our life. It has many sources whether through technological source or face to face. The language is very much important for communication. In case if our communication language is same and understood by everyone then mutual language should be used with the help of which we can communicate with the other people. The first language one learns as a child is the mother tongue. Reading and writings of other languages enable us to communicate with other people .The learning of a new language has a great scope in our lives. English has been used as a communicating language for many years as it's an international language which helps us to interact with different people and situations. The use of English language in the academic and professional life of the students is of paramount importance. It is an effective tool to improve the performance of students in oral and written communication. In addition to students, faculty members of academic institutes experience a lot of difficulties while communicating in English language. As a result of this, most of the students have been failed at graduation level. The others who have passed English as a subject they always found it very difficult to mark English as an interesting subject therefore students are advised to improve their communication skills in English to increase their chances and opportunities in professional life. Several factors persist which might cause our bad performance in English language that might be attributed to motivation and attitude towards English language. Motivation has been regarded as a key factor in learning of something. McDonough (1983) stated that motivation of the students is one of the most important factors influencing their success or failure in learning language. Motivation involves the study of many factors like student teacher relationship, self-respect and class room circumstances because it is a much understood feeling that you cannot perform well in a stressful and tense condition. If there is a gap present between the student and teacher, it will obviously create problems for learners in the classroom.

\subsection{Motivation}

This section presents an overview of the literature relevant to the proposed research objectives comprising of a brief overview of the concepts of motivation and attitudes from the relevant studies. The etymology of 'Motivation' is hard to express in simple words. Gardner (2006) stated that motivation is a much diversified complex phenomenon with many perspectives hence it is difficult to express it in simple words. Actually motivations are the options through which people decide their goals and aims. They also measure how much effort they have to exert in that respect. Students who 
have higher level motivation will do much better than others. (Schunk et al., 2008). Motivation has been described as a practice whereby goal directed activity is achieved or sustained. It can also be described in terms of external or internal factors that evoke desire and energy in people to be interested and committed to a job role or a subject or a situation. There are several schools of thoughts, envisaging the phenomena of motivation. From behavioural perspective, motivation can be termed as an anticipation of reward (Brown, 2000). However from cognitive aspect, motivation is a choice people opt as according to their experiences, extent of their effort or propose which they will approach. Motivation can be classified into following different types.

\subsection{Integrative and Instrumental motivation}

In integrative motivation students just want to know the target language and get to know the people who speak English. Integrative motivation describes an openness to identify with another language community. Instrumental motivation is for the sake of a practical reason such as getting a job/salary and bonus, as a source to get social and economic opportunities. Brown (2000) stated that learners should have the better understanding of this combination for learning process.

\subsection{Intrinsic and Extrinsic motivation}

Motivation can also be classified as Intrinsic and Extrinsic. First one is stem out of one's interests and desires. Intrinsic means internal or inside of yourself. When you are intrinsically motivated, you enjoy an activity, course or skill development solely for the satisfaction of learning and having fun, and you are determined to strive inwardly in order to be competent. There is not external inducement when intrinsic motivation is the key to behaviour or outcome. And later involves do something for the sake of something. Extrinsic means external or outside of yourself. This type of motivation is everywhere and frequently used within society throughout your lifetime. When you are motivated to behave, achieve, learn or do based on a highly regarded outcome, rather than for the fun, development or learning provided within an experience, you are being extrinsically motivated (Brown, 2000).

\section{Research background}

Kabilan (2000) indicated that there should be a mutual coordination between the tutor and student. Every student is different from one another therefore a teacher should use different creative styles and strategies in teaching. May be someone is inspired by this and have better chances for success (Widdowson, 1991). If success is important for motivation to learn more than teaching varieties becomes more important. A language teacher cannot teach a language properly if he or she is unable to understand the relationship between motivation and its effects upon language acquisition. All the students have inherent psychological needs and internal motives and reasons that engage them in classroom learning activities. They can perform effectively if teacher is supportive (Deci \& Ryan, 1985, 1991; Ryan \& Deci, 2000, 2002). The major source of motivation is passion (Champan \& Aspin, 1997). It is an obvious fact if you are passionate about some goal you can achieve it. Good learning is associated with learner's passion. If teacher is able to create positive and supportive environment in the class then the students would be more passionate to learn language so the class room environment should be student centred. At any study level we cannot ignore the role of student. Teacher can shift a student from passive to progressive learner. It is necessary that tutor transform to students some of their control over syllabus teaching and learning.

According to Macrof and D'cruz (2001), positive self-esteem, positive attitude, clear understanding of goals for language learning, the relevance of conductive environment can contribute to the success of language learning. It means that self-confidence is the key factor in learning a language. It provides us the positive energy in which we are enjoying the task and understand the real sense of communication.

Amato (2003) stated that successful language learners enjoy higher self-esteem than others. One of the most vital parts of second language learning is to keep students interested in learning. Student should feel himself powerful in speaking confidently in the classroom. Many sources can contribute to the lack of motivation which is beyond the control of the teacher. The student cannot perform in a stressed condition (Lile, 2002).

Lifrieri $(2005$, p. 4) concluded that motivation mostly affects the second language learning (SLL). Without proper motivation, language cannot be learned. But one cannot deny the fact that motivation can be affected if a student is feeling discomfort in the class and he or she disliked the teacher methodology and style.

In Japan, Ebata (2008) showed in his findings that motivation is very much significant in learning; accompanied selfconfidence, experience of success, and a good teacher relationship. He claimed that the co-ordination of these three factors is very much important in learning a new language.

In China, Kyriacou and Zhu (2008) explained the perception of students regarding their motivation and their perceived influences on others and the findings indicated that these students English learning motivation is dominated by life and career based reasons rather than integrative one. The motivation plays a pivotal role in the learning of new language.

Pineda (2011) examined the relationship between attitude and motivation among Mexican University students across three undergraduate programs. She used qualitative as well as quantitative techniques in which she selected various tools like, survey, interviews, and class observations. Her findings showed students interest in second language, motivational intensity to learn and teacher's evaluation impact upon student's performance in their English exams. Interviews and observations were proved as most effective tools which suggested that continuous and accurate English program evaluation is important in Mexican universities for the welfare of students and society in general.

Pan et al. (2010) conducted a survey in Qingdao Agriculture University. They divided the students into two groups named as Advanced English group and Ordinary English class. They took total 50 students for their works out of which 25 belonged to advanced class and 25 were included in ordinary class. For this purpose, they developed a questionnaire 
written by Gaoyen. Their findings showed that more students were motivated by intrinsic motivation in comparison to Ordinary English also suggested that class and their achievement level was higher than the second group. Logically intrinsic motivation is very much essential for English language learning. They also suggested that teachers should engage their students in enhancing intrinsic motivation. This is possible in such a situation in which there lies a trust worthy relationship between the tutor and pupil.

Ibrahim Humaida (2012) examined the level of motivation among the students of Islamic University of Sudan. It was descriptive in nature and simple random sample consisted of $(n=40)$ male students. The results showed that motivation scores were higher among students and there was no correlation between motivation and age. They recommended that students should be aware of learning process and we should keep learners in touch with modern teaching methods.

There has been done a lot of work upon motivation in Pakistan. A lot of researchers have showed in their studies that students take English language learning instrumentally to get a better opportunity. They do not learn it for pleasure. Several reasons are responsible for Pakistani learner's instrumental approach towards English language. We can name them as self-confidence, motivation, teacher-student relation, classroom environment, cultural background, home atmosphere etc.

Hashwani (2008) conducted a survey in private schools of Karachi. Her findings showed that motivational activities can cast a positive or negative effect on learning procedure furthermore she claimed that self-confidence plays a vital role in a learning process.

In Pakistan Sheikh et al (2014) showed in their research that tutors dominant teaching styles have great impact upon students. This study was planned to show the impact of various strategies upon student's motivational level. It was conducted in private school branches. Total 12 secondary school teachers with different styles were taken as a sample. This study was held to provide some insight into motivational level of secondary school students towards different styles. It was conclude that different teaching practices have a great role in learning process. The most popular style was Delegator style that was student centred. Students promoted this style a lot. Other styles were less important.

Rehman et al (2014) by using quantitative method with 50 students as a sample show that $70 \%$ students are instrumentally motivated and $24 \%$ were integratively interested in learning English language. This study also recommended that instructor should design their lesson according to student's psyche and this thing will help the tutor for motivating his student.

\subsection{Context of the Research}

The present research is totally different from above mentioned researches because I have focused upon motivational factors like teacher student relationship class room environment self confidence and external praise. Other researchers used the survey method and interviews but i formed questionnaire on 4 point Likert's scale. My research was qualitative and descriptive in nature. My questionnaire was consisted of 22 questions. My findings highly affirm the truth that motivational factors had great role in learning so a teacher should consider these factors for better performance.

\subsection{Research objectives}

The main objective of present research is to find out:

- the reasons behind low motivation in English language learning at undergraduate level

- the reasons for the communication gap between the students and teachers

- the reasons for students' less self-confidence

- the reasons for the difficult classroom conditions for students

\subsection{Research questions}

- Is there some communication gap between learner and teacher?

- Why most of the students are less self-confidant?

- Are the classroom conditions difficult for students or they are not valued in the class?

- What is the role of demotivation on the learners' performance?

\section{Methodology}

The main purpose of this research is to explore undergraduate students' motivational orientations towards English language learning. The researchers used the tool of questionnaire for this paper. In descriptive research we can collect data from many sources. In this study qualitative method has employed. The present study examines the impact of motivational factors upon learning foreign language.

\subsection{Data collection, population and sampling}

Firstly, the researchers took population from University of Sargodha (UoS), Women Campus Faisalabad and selected students from undergraduate level. From the accessible population, a convenient sample of 199 students has been taken. These students were easily approachable for the present research. The distribution of the students is as under.

Female students of University of Sargodha (UoS), Women Campus Faisalabad are taken as a sample of this research because they were easily available. The total strength of the students is 199 that is purposefully taken from the BS (Hons) students of various departments an disciplines. The discipline wise distribution of the participants have been shown in the Table 1. 
Table 1. Discipline wise distribution of total no. of students

\begin{tabular}{lc}
\hline \multicolumn{1}{c}{ Department / Discipline } & No. Of Students \\
\hline BS Physics & 10 \\
\hline BS Chemistry & 41 \\
\hline BS Zoology & 40 \\
\hline Bachelors in Business Administration(BBA & 12 \\
\hline BS English & 10 \\
\hline BS Botany & 08 \\
\hline BS Software Engineering & 59 \\
\hline BS Mathematics & 19 \\
\hline Total no. (n) & 199 \\
\hline
\end{tabular}

The general characteristics of the participants have been given in the Table 2 below.

Table 2. The general characteristics of the participants

\begin{tabular}{ll}
\hline No of students & 199 \\
\hline Age & $19-22$ years \\
\hline Gender & Female \\
\hline Class & Undergraduate level \\
\hline Institute & University of Sargodha women campus Faisalabad \\
\hline
\end{tabular}

\subsection{Instrument of the study}

To measure the causes which affect motivation the researchers formed a questionnaire based upon 4-point Likert scale. The questionnaire consisted of 22 questions. It was based upon four options SA: Strongly Agree, AG: Agree, DA: Disagree, SD: Strongly Disagree. The researchers took opinion from the students for this purpose and asked them to choose one suitable answer from the 4 options. It was designed to find the real thinking of the students towards English language motivation and motivation in the English language classes. The students were requested that they should answer all the questions carefully and honestly and were assured them that their responses will be kept secret so they should not answer in a prejudiced way. Students were given the maximum time to solve the questionnaire. For their convenience the researchers explained every question into Urdu and Punjabi language as well.

\section{Results \& Discussion}

All the students were asked different questions related to motivational factors. In the questionnaire they admitted that motivational factors had a great role in learning English language. The questionnaire consisted of 22 questions containing 4 options Strongly Agree (SD), Disagree (DA), Strongly Agree (SA), Agree (AG).

Table 3. Over all response of the participants in $\%$ and no.

\begin{tabular}{|c|c|c|c|c|c|}
\hline No. & SD & DA & SA & & $\mathrm{G}$ \\
\hline 1. & $17.08 \% \quad(34)$ & $11.55 \%$ & $35.17 \%$ & $36.18 \%$ & $(72)$ \\
\hline 2. & $15.5 \%$ & $27.1 \%$ & $30.1 \% \quad(60)$ & $27.1 \%$ & (54) \\
\hline 3. & $7.53 \% \quad(15)$ & $8.54 \% \quad$ (17) & $46.23 \%(92)$ & $37.68 \%$ & (75) \\
\hline 4. & $(14)$ & $2.51 \% \quad(5)$ & $62.81 \%(125)$ & $27.63 \%$ & (55) \\
\hline 5. & (18) & $19 \%$ & $27.63 \% \quad(55)$ & $44.22 \%$ & (88) \\
\hline 6. & $14 \%$ & $25.62 \% \quad(51)$ & $33.66 \% \quad(67)$ & $26.63 \%$ & (53) \\
\hline 7. & $15 \% \quad(30)$ & $14.57 \% \quad(29)$ & $29.64 \% \quad(59)$ & $40.70 \%$ & (81) \\
\hline 8. & $12.5 \% \quad(25)$ & $14 \%$ & $32.66 \% \quad(65)$ & $40.70 \%$ & (81) \\
\hline 9. & $16 \%$ & $18 \% \quad(36)$ & $35.67 \%(71)$ & $30.15 \%$ & (60) \\
\hline 10 . & $5.52 \%(11)$ & $5 \% \quad(10)$ & $59.79 \%(119)$ & $29.64 \%$ & (59) \\
\hline 11. & $6.53 \% \quad(13)$ & $8 \% \quad(16)$ & $51.75 \%(103)$ & $33.66 \%$ & (67) \\
\hline 12. & $6.53 \%(13)$ & $13.56 \% \quad(27)$ & $45.72 \%(91)$ & $34.17 \%$ & (68) \\
\hline 13. & $6 \% \quad(12)$ & $4.52 \% \quad(9)$ & $62.31 \% \quad(124)$ & $27.13 \%$ & (54) \\
\hline 14. & $20.1 \% \quad(40)$ & $27.63 \% \quad(55)$ & $23.61 \% \quad(47)$ & $28.64 \%$ & (57) \\
\hline 15. & $6.53 \%(13)$ & $5.52 \% \quad(11)$ & $44.22 \%(88)$ & $43.71 \%$ & (87) \\
\hline 16. & $6 \% \quad(12)$ & $4 \% \quad(8)$ & $61.3 \% \quad(122)$ & $28.64 \%$ & (57) \\
\hline 17. & $12.5 \%(25)$ & $15.53 \%$ & $37.68 \% \quad(75)$ & $34.17 \%$ & (68) \\
\hline 18. & $5 \% \quad(10)$ & $10.55 \% \quad(21)$ & $39.19 \% \quad(78)$ & $45.22 \%$ & (90) \\
\hline 19. & $5 \% \quad(10)$ & $5.52 \% \quad(11)$ & $45.22 \% \quad(90)$ & $44.22 \%$ & (88) \\
\hline 20 . & $13.56 \% \quad(27)$ & $14.57 \% \quad(29)$ & $33.16 \% \quad(66)$ & $38.69 \%$ & (77) \\
\hline 21. & $5 \%$ & $5.525 \quad(11)$ & $49.74 \%$ & $36.69 \%$ & (79) \\
\hline 22. & $18.59 \%$ & $18 \%$ & $36.18 \% \quad(72)$ & $27.13 \%$ & (54) \\
\hline
\end{tabular}


In response of first question $36.18 \%$ respondents agreed that it is very difficult for a student to perform in a difficult class room environment and $35.17 \%$ people strongly agree upon this, while $17 \%$ strongly disagreed and $11.55 \%$ disagreed with this fact (Figure 1). So if we calculate agreed and strongly willing persons it is about $71.35 \%$ and the total of disagreed and strongly disagreed is only $29 \%$ that is lesser than agreed persons. So, the findings highly support the factor that a class room environment should be comfortable according to the needs of learners. So my results clearly recommend the statement of Lile (2002) in which he stated that it is very tough for a learner if the classroom environment is disturbing.

In the answer to the second question majority of the ratio of $30.1 \%$ strongly agreed and $27.1 \%$ agreed indicated that class room environment should focus on student while $15.5 \%$ strongly disagreed and $27.1 \%$ only disagreed. The total agreed persons are $57 \%$ while disagreed ratio is $43 \%$. As the Figure 1 shows, the results highly favour student centered environment.

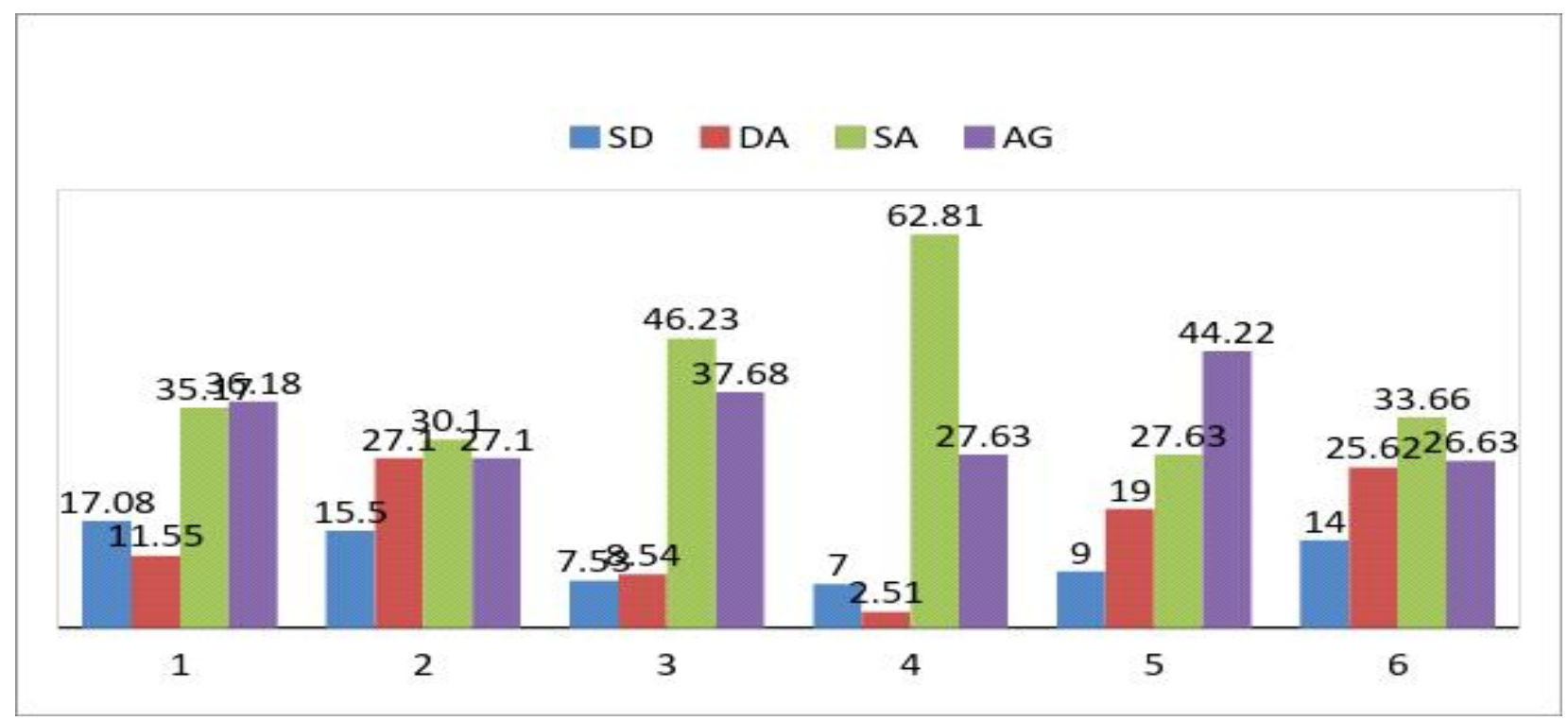

Figure 1. Results of survey based on questionnaire's series from 01 to 6 .

Then in question three $46.23 \%$ students strongly accepted that their language teacher uses different ways for their understanding. On the other hand $37.68 \%$ agreed, $8.54 \%$ disgreed and $7.53 \%$ strongly disagreed. The sum of willing persons in question 3 is $84 \%$ and other non willing persons are only $16 \%$. So the findings of question 3 are highly recommending the importance different practices and ways when we learn second language.

In question no. $4,62.81 \%$ strongly agreed $27.63 \%$ only agreed while $2.51 \%$ disagreed and $7 \%$ strongly disagreed. The total of agreed learners are $90.44 \%$ and $10 \%$ are not willing persons. So the results in question no 4 show that by using different activities and examples we can enhance motivation.

For question no. 5, 44.22\% admitted the fact that management of a classroom by the tutor shows his own belief upon the subject and the ratio of strongly agree is $27.63 \%$. The percentage of disagree 19 and strongly disagree is 9 . The sum of agreed persons is $72 \%$ and disagreed people are only $28 \%$.

If we take a look upon question no. 6 , we can see that $33.66 \%$ are strongly favouring the point that teacher should avoid those tests and exercises which are a great cause of failures because failure has been a great hurdle in learning $26.63 \%$ also admitted the fact of failure and only $25.62 \%$ disagreed while $14 \%$ strongly disagreed the following question. The calculated ratio of agreed persons is $60 \%$ and disagreed only $40 \%$. The Figure 2 shows responses from question no 7 to 12.

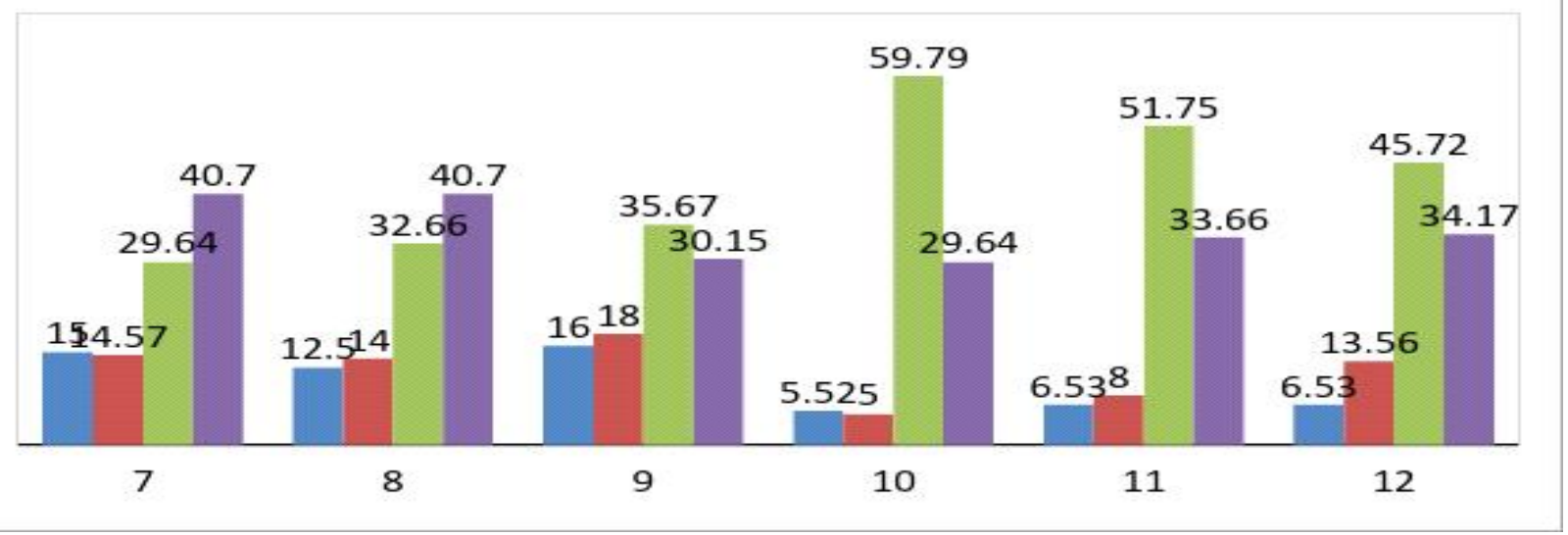

Figure 2. Results of survey based on questionnaire's series from 7 to 12 . 
In the answer of question no. 7, 40.7\% students were in the support of reduced sized language group and the percentage of strongly agreed was $29.64 \%$. The ratio of disagree was $14.57 \%$ while strongly disagreed were $15 \%$.The sum of agreed is $70 \%$ and disagreed only $30 \%$.

In question 8 , so far as the importance of group learning process is concerned $40.7 \%$ were favouring this question and $32.66 \%$ were strong follower. So these percentages suggest that a language teacher should consider group process if he/she wants to maintain the learning process in the class. $14 \%$ disagreed and $12.56 \%$ strongly opposed that. The total of agreed is $73 \%$ and disagreed $27 \%$.

While discussing the cultural issues in question no. 9, students with $35.67 \%$ strongly agreed that a teacher should consider the cultural differences and $30.15 \%$ also supported the fact. Only $18 \%$ disagreed and $16 \%$ strongly disagreed. The total no of agreed learners upon cultural issues are $66 \%$ and disagreed only $34 \%$.

In point no. 10, about $59.79 \%$ claimed that if they enjoy successful experience then their motivation level is increased to pursue a new task and they had the support of $29.64 \%$ agreed students. The ratio of disagree and strongly disagreed is $5 \%$ and $5.52 \%$. The sum of agreed is $89 \%$ and disagreed only $11 \%$ highly supports the statement that experience of success gives learners a high motivation level for attaining their new goal.

$51.75 \%$ strongly proved the importance of student teacher frank relationship and $33.66 \%$ also admitted that if your language teacher is frank with you then your performance would be much better in class. $8 \%$ disagreed and $6.53 \%$ strongly disagreed. The total ratio that supports frank tutor student relationships is $85 \%$ while on the other hand total disagreed are only $15 \%$. So the results clearly support the statement of Kabilan (2000) that there should have been comfortable relationship between student and pupil.

In response to question no. 12, 45.72\%were agreed that external satisfaction or appreciation is vital for good performance in learning second language. They also got the support of $34.17 \%$ agree people. We have $13.56 \%$ disagree and $6.53 \%$ strongly disagreed people. The total sum of supporting persons are $80 \%$ that shows that if a student gets external appreciation from tutor then he is more successful than others. While $20 \%$ is the total ratio of the disagreed one. The next table shows the figures of question 3 to 18 .

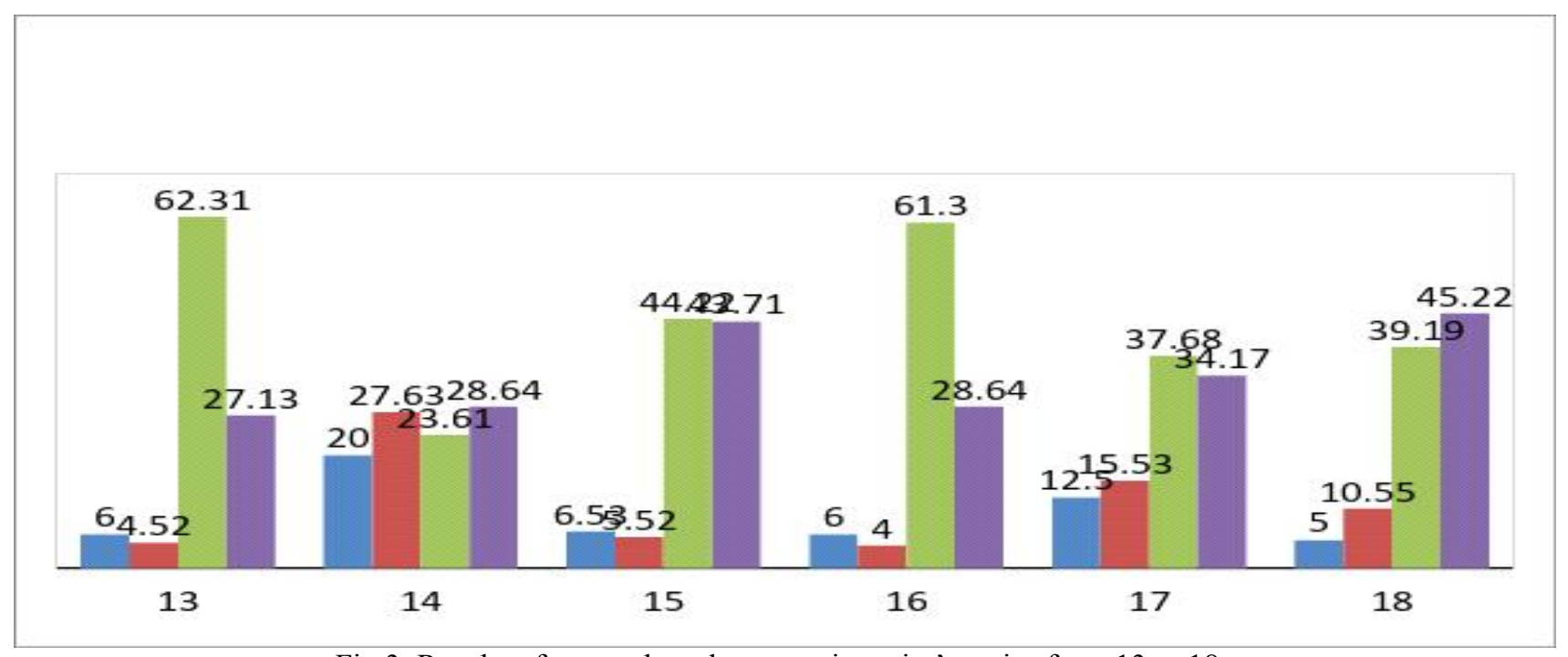

Fig 3. Results of survey based on questionnaire's series from 13 to 18

In point no 13 students with $62.31 \%$ showed that self-confidence plays a great part in our learning as (Ebata, 2008) showed in his findings that self confidence maintains the positive energy in us that helps us in our learning process. $27.13 \%$ were agreed $4.52 \%$ disagreed and $6 \%$ strongly opposed it (Figure 2). The sum of supportive persons are $89 \%$ while remaining are only $11 \%$.

For question no. 14, about $28.64 \%$ agreed that English is too difficult to understand $23.61 \%$ strongly agreed with them. Remaining was $27.63 \%$ disagreed and $20.1 \%$ strongly disagreed. The total of agreed student is $52 \%$ while $48 \%$ are disagreed one who does not consider English as difficult subject.

For question no. 15 , about $43.71 \%$ admitted the reality and agreed on the opinion that self-value is a necessary thing for doing any sort of chore. $44.22 \%$ strongly supported them and on the other hand disagreed and strongly disagreed were $5.52 \%$ and $6.53 \%$ respectively. The calculated ratio in this question is $88 \%$ agreed and $12 \%$ disagreed.

In a reaction to question no 16 we have a large ratio of $61.30 \%$ strongly passionate persons accompanying with them $28.64 \%$ agreed students. Disagreed are $4 \%$ and strongly opposed are only $6 \%$. The sum of agreed one is $90 \%$ while disagreed are only $10 \%$.So in this question it is highly suggested that passion is very much vital in our learning process. So my results clearly suggest the statement of (Champan and Aspin, 1997) that if a teacher creates a trust worthy relationship among the students then ratio of passionate students would be increased because we cannot learn without passion. 
In question 17 majority with $37.68 \%$ understood the place of home background in acquiring a foreign language $34.17 \%$ also supporting the idea and $15.57 \%$ only disagreed with that but $12.56 \%$ strongly deny the fact of home background importance. So the total no of supportive argument is $72 \%$ while disagreed are only $28 \%$.

In question 18 we have $45.22 \%$ agree, $39.19 \%$ strongly agreed $10.55 \%$ disagree and $5 \%$ strongly disagreed. The sum of agreed is $84 \%$ while disagreed areonly $16 \%$. The Figure 3 shows response in percentages of question 19 to 22 .

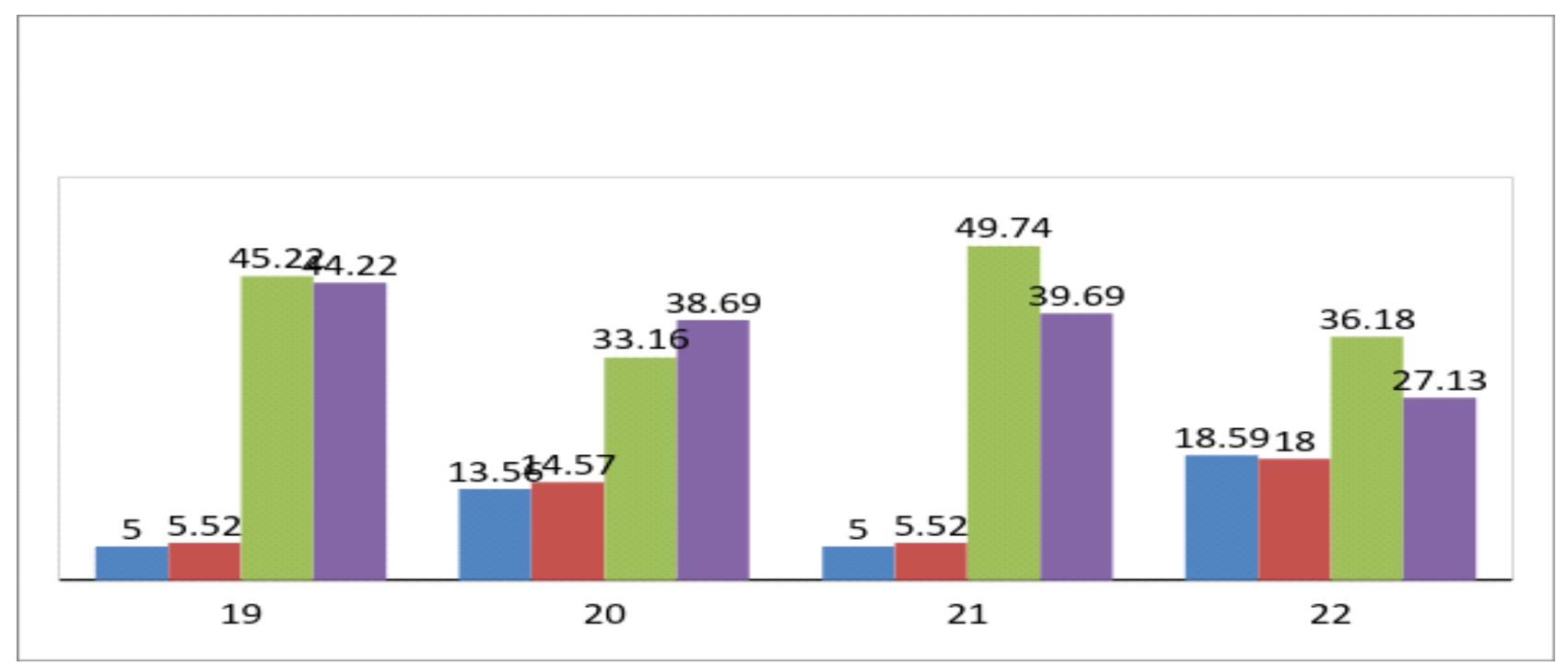

Figure 4. Findings of survey based on questionnaire's series from 19to 22 .

About $45 \%$ strongly claimed that if the class room atmosphere is motivating then they are safe secure and orderly. $44 \%$ agreed $6 \%$ disagreed and only $5 \%$ highly disfavoured it (Figure 4 ). The total of favouring learner is $89 \%$ and disagreed are only $11 \%$ in sum.

In point no. 20, we have $39 \%$ agree and 33\% strongly agree pupils' and $15 \%$ disagreed it. We have only $14 \%$ people having strong opposite opinion. The total sum of agreed is $72 \%$ while disagreed are only $29 \%$ in total.

In question no 21, results showed that if someone is successful then he/she had a good knowledge about his/her talent. In this regard, we have 50\% strong support and $40 \%$ agreed persons. $6 \%$ disagreed and $5 \%$ strongly disagreed upon it. So in this question we have total of $90 \%$ agreed ones while on the other hand disagreed persons are only $11 \%$.

In the final question 36\% strongly supported the opinion that we learn English only for extrinsic purpose like for a job or some reward. We have no intrinsic motivation for English language. $27 \%$ agreed while disagree and strongly disagreed are $18 \%$ and $19 \%$, respectively. The total sum of agreed is $63 \%$ while others having disagreed with this question are 37\%. The findings clearly matched with Rehman et al (2014) in which 70\% students were learning English language only to get some reward or job. Likewise in my studies students were only extrinsically motivated to learn English language so they can have better future opportunities.

\section{Conclusion}

Motivation had a peripheral importance in accordance to the factors like self-confidence, class room condition, passion and role of student teacher in the class. The findings showed the importance of the facts that we cannot move forward if these factors are not properly treated. We can see that the majority of our students is not able to speak English fluently nor they can write it well. The very reality behind the scene is that our language teachers are failed to coordinate with the students. Teacher applies the same practices that cannot help to motivate students in English language class. When a student fails his confidence level shatters and in the end he is unable to learn a foreign language. Moreover, the results indicated that if the factors can be utilized in a right direction then we can get much better results. Our main goal should be to impart quality knowledge nor to make realize students that English is only a burden for them that are something beyond their approach. The results also answered my question that why students fail in English language. The reasons were that our learners are not passionate in learning because there is no healthy relationship between student and teacher. As the findings of point 16 shows that passion is an important part of learning English language.

\section{References}

Brown, H.D. (2000). Principles of language learning and teaching. New Jersey: Prentice Hall.

Chapman, J. D., and Aspin, D. N. (1997). The school, the community and lifelong learning. London, Cassell:Wellington House.

Deci, E. L., and Ryan, R. M. (1985). Intrinsic motivation and self-determination in human behaviour: New York: Plenum Press.

Deci, E. L., and Ryan, R. M. (1991). A motivational approach to self: Integration in personality. In R. Dienstbier (Ed.), Nebraska symposium on motivation: Perspectives on motivation. (Vol. 38, pp. 237-288). 
Gardner, R. (2006). The socio-educational model of second language acquisition: a research paradigm. EUROSLA Yearbook, 6, 237-260.

Gardner, R. C., Day, J.B., and Macintyre, P.D. (1992).Integrative motivation, induced anxiety, and language learning in a controlled environment. Studies in Second Language Acquisition, 14(2), 197-214.

Guirong Pan,Yiming Zang,Dan Wu. (2010) Journal of Language Teaching and Research, Vol. 1, No. 2, pp. 151-156.

Hashwani, M. S. (2008). Students' attitudes, motivation and anxiety towards English language learning. Journal of Research and Reflections in Education, 2(2).

Hussin, S., Maarof, N., and D'Cruz, J. (2001). Sustaining an interest in learning English and Increasing the motivation to learn English: an enrichment program.

Ibrahim Humaida, I. A. (2012). Motivation to Learn Among English Language Learners in Sudan. 1: 237. doi:10.4172/scientificreports.237.

Kabilan, M. K. (2000). Creative and critical thinking in language classrooms. The Internet TESL Journal, 6 (6).

Kyriacou, C. and Zhu, D.(2008). Shanghai pupil's motivation towards learning English and the perceived influence of important others. Educational Studies. Vol. 34, No. 2, May 2008, 97-104.

Lifrieri, V. (2005). A sociological perspective on motivation to learn EFL: The case ofescuelas plurilingües in Argentina. M.A thesis, University of Pittsburgh.

Lile, W. (2002). Motivation in the ESL classroom. The Internet TESL Journal, 8 (1). http://iteslj.org/Techniques/Kabilan-CriticalThinking.html. [retrived 10-09-2014]

Ebata, M. (2008). Motivation factors in language learning. The Internet TESL Journal, 14(4). Retrieved from http://iteslj.org/Articles/Ebata-MotivationFactors.html on 12-09-2014.

McDonough, S. (1983). Psychology in foreign language teaching. George Allen \&Unwin: London.

Hussin, S., Maarof, N., \& D'Cruz, J. (2001). Sustaining an interest in learning English and increasing the motivation to learn English: an enrichment program. The Internet TESL Journal,7 (5). http://iteslj.org/Techniques/Hussin-Motivation/ [retrieved 15-09-2014]

Amato, P. A., (2003). Making it happen: From interactive to participatory Language teaching: theory and practice. White Plains, NY: Pearson Education.

Ryan, R. M., and Deci, E. L. (2000). Self-determination theory and the facilitation of intrinsic motivation, social development, and well-being. American Psychologist, 55, 68-78.

Ryan, R. M., \& Deci, E. L. (2002). An overview of self-determination theory: An organismic dialectical perspective. In E. L. Deci \& R. M. Ryan (Eds.), Handbook of self-determination research (pp. 3-33).Rochester, NY: University of Rochester.

Rehman, A. Sheikh, A, Bilal, A. H, Bibi, N, and Nawaz, A. (2014). The Role of Motivation in Learning English Language for Pakistani Learners. International Journal of Humanities and social Science, Vol.4, No. 1.

Sheikh, A. \& Mahmood, N. (2014). Effect of different teaching styles on students' motivation towards English language learning at secondary level. Sci.Int(Lahore), 26(20), 825-830.

Schunk, D. H., Pintrich, P. R., and Meece, J. L. (2008). Motivation in education: theory, research, and Applications. ). Upper Saddle River, NJ: Pearson Merrill Prentice Hall.

Widdowson, H.G. (1991) Aspects of Language Teaching, Oxford: Oxford University Press. 


\section{APPENDIX: Students' Motivation Questionnaire}

Introduction: This questionnaire is designed to find the real thinking of students towards English language learning. Please answer to all questions carefully and honestly. Your answers or responses will be kept in secret. Please do not answer in a prejudice way. The following abbreviations have been used for your convenience: SA: Strongly Agree; AG-Agree; DA-Disagree; SD-Strongly Disagree.

Name:

Gender:

Class:

Age:

\begin{tabular}{|c|c|c|c|c|c|}
\hline No. & Item Description & SD & DA & $\mathbf{S A}$ & $\mathbf{A G}$ \\
\hline 1 & It is very difficult for a student to perform in a tense environment. & & & & \\
\hline 2 & Class environment should be student centered. & & & & \\
\hline 3 & Your language teacher uses different strategies for your understanding. & & & & \\
\hline 4 & $\begin{array}{l}\text { Teacher can increase motivation to learn by beginning lessons with } \\
\text { examples, activities, or questions. }\end{array}$ & & & & \\
\hline 5 & $\begin{array}{l}\text { A teacher's classroom management system shows information about } \\
\text { teacher's belief on content and learning process. }\end{array}$ & & & & \\
\hline 6 & Tutor and teacher should avoid those practices that guarantee failure. & & & & \\
\hline 7 & Language learning group size should be reduced or not. & & & & \\
\hline 8 & $\begin{array}{l}\text { Maintaining the learning process requires teacher to focus on group } \\
\text { processes. }\end{array}$ & & & & \\
\hline 9 & Teacher should understand cultural differences in the class. & & & & \\
\hline 10 & $\begin{array}{l}\text { Experience of success provides student with more power to pursue a new } \\
\text { goal. }\end{array}$ & & & & \\
\hline 11 & There should be a frank relationship between the teacher and student. & & & & \\
\hline 12 & $\begin{array}{l}\text { External praise is very much important for a better performance in the } \\
\text { class. }\end{array}$ & & & & \\
\hline 13 & Self confidence is most vital part in the class. & & & & \\
\hline 14 & Students consider English as a difficult subject. & & & & \\
\hline 15 & $\begin{array}{l}\text { If students feel valued they are more likely to be motivated to learn second } \\
\text { language. }\end{array}$ & & & & \\
\hline 16 & Passion is necessary for learning English as a second language & & & & \\
\hline 17 & Your personal home background affects your learning. & & & & \\
\hline 18 & $\begin{array}{l}\text { In motivating environments students understand what they are expected to } \\
\text { do so and why they are expected to do so. }\end{array}$ & & & & \\
\hline 19 & $\begin{array}{l}\text { Motivating environments are safe secure and orderly places that focus on } \\
\text { learning. }\end{array}$ & & & & \\
\hline 20 & $\begin{array}{l}\text { Leaning focused environments increase motivation while performance } \\
\text { focused environments classrooms can detract motivation. }\end{array}$ & & & & \\
\hline 21 & Successful learners know their abilities and strengths. & & & & \\
\hline 22 & English is learned for pleasure or only for a job and career. & & & & \\
\hline
\end{tabular}

